\title{
Molecular Genetic Analysis of Primary Renal Epithelial Tumours with Granular Oncocytic Cytoplasms
}

\author{
Análisis Genético Molecular de Tumores Epiteliales Renales \\ Primarios con Citoplasma Oncocítico Granular
}

Sandra Trivunic Dajko ${ }^{1,2}$; Jovo Bogdanovic ${ }^{3,4}$; Bojana Andrejic Visnjic ${ }^{5}$; Milan Popovic ${ }^{5,6}$; Matilda Djolai ${ }^{2,5}$ \& Ondrej Hes $^{7}$

TRIVUNIC DAJKO, S.; BOGDANOVIC, J.; ANDREJIC VISNJIC, B. A.; POPOVIC, M. ; DOJLAI, M. \& HES, O. Molecular genetic analysis of primary renal epithelial tumours with granular oncocytic cytoplasm. Int. J. Morphol., 39(6):1719-1726, 2021.

SUMMARY: The group of primary renal tumours with granular-oncocytic cytoplasm is a very heterogeneous group, in its histological origin and biological behavior resulting in many diagnostic problems. In this study 57 renal epithelial tumours with granular oncocytic cells were analyzed using fluorescence in situ hybridisation (FISH), array comparative genomic hybridisation (aCGH) and polymerase chain reaction (PCR). The results of analysis in renal oncocytoma (RO) did not indicate the presence of the gene mutations or chromosomal abnormalities. Sporadic renal hybrid oncocytic/chromophobe tumours (HOCT) had multiple numerical aberrations of chromosomes 1, 2, 6, 9, 10, 13, 17, 20, 21 and 22. This type of tumour had no mutations in the VHL, c-kit, PDGFRA, and FLCN genes. Oncocytic papillary renal cell carcinoma (O-PRCC) had numerical abnormalities of chromosomes 7 and 17 and the loss of the Y chromosome. Cytogenetic analysis of 20 pigmented microcystic chromophobe renal cell carcinomas (PMChRCC) showed monosomy as the most frequent aberration in all analyzed chromosomes 1,2, 5, 10, 13, 17 and 21. One case of chromophobe renal cell carcinoma (ChRCC) with hyaline globules had a mutation in the distal part of exon 3 of the VHL gene. Absence of genetic disorders in usual RO is common result, but we have established absence of genetic disorders even in rare variants. Variety of genetic alterations detected in sporadic renal HOCT proves it to be a separate entity, not a variant of ChRCC, while PMChRCC is an uncommon variant of ChRCC. O$\mathrm{PRCC}$ is a subtype of papillary renal cell carcinoma.

KEY WORDS: Renal tumours; Granular oncocytic cytoplasm; Molecular genetic analysis.

\section{INTRODUCTION}

In the daily work of a pathologist specialized in urological pathology, a group of primary renal tumours with granular-oncocytic cytoplasm causes many dilemmas and problems. This is a very heterogeneous group, in its histological origin and biological behaviour, which results in a difference in treatment and prognosis of the disease. Accurate pathohistological diagnosis of this group of tumours contributes significantly to the diagnosis and treatment of patients. The group includes the following types of tumour: 1. renal oncocytoma (RO), 2. renal hybrid oncocytic/chromophobe tumour (HOCT) with or without evidence of the Birt-Hogg-Dubé syndrome (BHD), 3. oncocytic papillary renal cell carcinoma (O-PRCC), 4. chromophobe renal cell carcinoma (ChRCC), 5. eosinophilic variant of clear cell renal cell carcinoma (granular RCC) and 6. oncocytoma-like epithelioid angiomyolipoma (epithelioid PEComa) which belongs to the soft tissue tumours, and will not be the subject of analysis in this paper (Bostwick \& Cheng, 2008; McKenney et al., 2010).

In many cases, standard hematoxylin and eosin (HE) and immunohistochemical staining are not sufficient to reach a definitive diagnosis of these tumours, an important factor are molecular genetic analyses, which provide answers, and indicate the specific genetic alterations related to individual diseases (Merino et al., 2004).

\footnotetext{
${ }^{1}$ University of Novi Sad, Faculty of Medicine, Department of pathology, Hajduk Veljkova 3, Novi Sad, Serbia.

${ }^{2}$ Clinical Centre of Vojvodina, Centre for Pathology and Histology, Hajduk Veljkova 1, Novi Sad, Serbia.

${ }^{3}$ University of Novi Sad, Faculty of Medicine, Department of surgery, Hajduk Veljkova 3, Novi Sad, Serbia.

${ }^{4}$ Clinical Centre of Vojvodina, Clinic of Urology, Hajduk Veljkova 1, Novi Sad, Serbia.

${ }^{5}$ University of Novi Sad, Faculty of Medicine, Department of histology and embryology, Hajduk Veljkova 3, Novi Sad, Serbia.

${ }^{6}$ Oncology Institute of Vojvodina, Put dr Goldmana 4, Sremska Kamenica, Serbia.

${ }^{7}$ Charles University Hospital Plzen, Department of Pathology, Plzen, Czech Republic.
} 
Many genetic alterations have been reported among this group of tumours (Allory et al., 2003; Brunelli et al., 2003; Adley et al., 2006; Gatalica et al., 2009; Kluijt et al., 2009), but usually in a single type or just one case. The purpose of this study was to represent single center experience for previous 10 years, in the use of molecular genetic methods in the identification of genetic changes of primary renal epithelial tumours with granular oncocytic cytoplasm.

\section{MATERIAL AND METHOD}

Samples: The study was retrospective, and it included 57 renal epithelial tumours with granular oncocytic cytoplasm, classified into 5 groups: 1 . RO ( 7 cases with vascular invasion (vRO) and 3 cases of small cell oncocytoma with pseudorosettes (psRO), 2. O-PRCC $(\mathrm{n}=12), 3$. sporadic HOCT $(n=14)$, 4. pigmented microcystic chromophobe renal cell carcinomas (PMChRCC) $(n=20), 5$. granular RCC with hyaline globules (gRCChg) $(n=1)$. These tumours were diagnosed in our institution during the period between 20112021. All test procedures were approved by the ethics committee.

Molecular genetic methods. The following molecular genetic, i.e. cytogenetic tumour tests were performed: fluorescence in situ hybridization (FISH), array comparative genomic hybridization (aCGH), and Sanger DNA sequencing PCR according to the manufacturer's specifications. Table I shows the applied methods of analysis, depending on the type of tumour. The detailed explanation of the applied methods can be found as following.

Fluorescence in situ hybridization methods. A 4- $\mu$ m-thick tissue section was placed onto a positively charged slide. Hematoxylin and eosin-stained slides were examined for the identification of areas for cell counting. The unstained slide was routinely deparaffinized and incubated in the $1 \times$ Target Retrieval Solution Citrate, pH 6 (DAKO, Glostrup, Denmark) for $40 \mathrm{~min}$ at $95^{\circ} \mathrm{C}$ and subsequently cooled for $20 \mathrm{~min}$ at room temperature (RT) in the same solution. The slide was washed in deionized water for $5 \mathrm{~min}$ and the tissue was treated with proteinase $\mathrm{K}(20 \mathrm{mg} / \mathrm{ml}$; SERVA, Heidelberg, Germany) for 4 min at RT. The slide was then placed into deionized water for $5 \mathrm{~min}$, dehydrated in a series of ethanol solution $(70 \%, 85 \%$, and $96 \%$ for $2 \mathrm{~min}$ each), and air-dried. Probes for detection of aneuploidy of chromosomes 1, 2, 6, 7, 9, 10, 13, 17, 20, 21 and 22 (VYSIS/ Abbott Molecular, Abbott Park, IL, USA; Table II) were mixed with water and LSI/WCP hybridization buffer (VYSIS/Abbott Molecular) in a 1:2:7 ratio. An appropriate amount of probe mix was applied on sections, covered with a glass coverslip, and sealed with rubber cement. Slides were incubated in the ThermoBriteTM instrument (StatSpin/Iris Sample Processing, Westwood, MA, USA) with codenaturation parameters $85^{\circ} \mathrm{C}$ for $8 \mathrm{~min}$ and hybridization parameters $37^{\circ} \mathrm{C}$ for $16 \mathrm{~h}$. The coverslip was then removed and the slides were placed in posthybridization wash solution $(2 \times \mathrm{SSC} / 0.3 \% \mathrm{NP}-40)$ at $72{ }^{\circ} \mathrm{C}$ for $2 \mathrm{~min}$. Slides were airdried in the dark, counterstained with DAPI II (VYSIS/ Abbott Molecular), cover slipped, and immediately examined.

Table II. Probes for aneuploidy detection of chromosomes $1,2,6,7,9,10,13,17,20,21$, and 22

\begin{tabular}{ll}
\hline & Cromosome Probe \\
\hline 1 & CEP 1 Satellite III \\
2 & CEP 2 (D2Z1) \\
6 & CEP 6 (D6Z1) \\
7 & CEP 7 (D7Z1) \\
9 & CEP 9 \\
10 & CEP 10 \\
13 & LSI 13 (RB1) \\
17 & CEP 17 (D17Z1) \\
20 & CEP 20 (D20Z1) \\
21 & LSI 21 \\
22 & LSI 22 (BCR) \\
\hline
\end{tabular}

The sections were examined using a $\times 100$ objective and either a triple bandpass filter set (DAPI/ SpectrumGreen ${ }^{\mathrm{TM}} /$ SpectrumOrange ${ }^{\mathrm{TM}}$ ) or single bandpass filters (SpectrumGreen or SpectrumOrange). Scoring of aneuploidy was performed by counting the number of fluorescent signals in $>100$ randomly selected nonoverlapping tumor cell nuclei. The slides were independently counted by two observers (PG and $\mathrm{OH}$ ).

Table I. Renal epithelial tumours with granular-oncocytic cytoplasm and molecular genetic methods applied.

\begin{tabular}{lllllll}
\hline & vRO & psRO & HOCT & O-PRCC & PMChRCC & gRCChg \\
\hline PCR & VHL, LOH & $/$ & c-kit, PDGFRA, VHL & $/$ & c-kit & VHL \\
FISH & 7,17 & $1,2,6,7,10,17$ & $1,2,6,9,10,13,17,20,21$ and 22 & $7,17, \mathrm{Y}$ & $1,2,6,10,13,17$ and 21 & $/$ \\
aCGH & X,Y & 7,17 & $/$ & $/$ & $/$ & $/$
\end{tabular}

vRO - renal oncocytoma with vascular invasion; psRO - small cell oncocytoma with pseudorosettes; HOCT - renal hybrid oncocytic/chromophobe tumour; O-PRCC - papillary renal cell carcinoma with oncocytic cytoplasm; PMChRCC - pigmented microcystic chromophobe renal cell carcinomas; gRCChg- granular renal cell carcinoma with hyaline globules. 
TRIVUNIC DAJKO, S.; BOGDANOVIC, J.; ANDREJIC VISNJIC, B. A.; POPOVIC, M. ; DOJLAI, M. \& HES, O. Molecular genetic analysis of primary renal epithelial tumours with granular oncocytic cytoplasm. Int. J. Morphol., 39(6):1719-1726, 2021.

Cutoff values were evaluated in the least 100 nonoverlapping cell nuclei in five normal non-neoplastic control tissues of kidney for each analyzed probe, i.e., 55 negative control fluorescence in situ hybridization (FISH) were performed. For monosomy, the average number of single signal was 28.1 and standard deviation 5.5. For polysomy, the average number of three or more signals were 4.0 and standard deviation 1.9. The monosomy and polysomy for the studied chromosomes were defined as the presence of one signal per cell in $>45 \%$ and three or more signals in $>10 \%$ (mean \pm 3 standard deviations in normal tissue, both rounded up), respectively.

c-kit, PDGFRA, and VHL mutation analysis. Genomic DNA for molecular genetic investigation was extracted from formalin-fixed, paraffin-embedded tissue. Several 5mmthick sections were placed on the slides. Hematoxylin and eosin-stained slides were examined for the identification of neoplastic tissue. Subsequently, neoplastic tumor and nonneoplastic tissue from unstained slides was scraped and DNA was isolated by the NucleoSpin $®$ Tissue Kit (MACHEREYNAGEL, Düren, Germany) according to the manufacturer's protocol. In several cases, where quality or amount of extracted DNA was low, genomic DNA concentration was perforned with the Microcon 100 (Millipore, Billerica, MA, USA) according to the manufacturer's protocol. Mutation analysis of exons 9, 11, 13 , and 17 of the c-kit gene, exons 12, 14, and 18 of the PDGFRA gene, and exons 1, 2, and 3 of the VHL gene was performed using PCR and direct sequencing. PCR was carried out using primers shown in Table III. The reaction conditions for all amplicons (except D3S666) were as follows: $12.5 \mu \mathrm{l}$ of HotStart Taq PCR Master Mix (QIAgen, Hilden, Germany), 10 pmol of each primer, $100 \mathrm{ng}$ of template DNA, and distilled water up to $25 \mu \mathrm{l}$. Temperature profile was as follows: denaturation at $95{ }^{\circ} \mathrm{C}$ for $15 \mathrm{~min}$ and then 40 cycles of denaturation at $95{ }^{\circ} \mathrm{C}$ for $1 \mathrm{~min}$, annealing at $55^{\circ} \mathrm{C}$ for $1 \mathrm{~min}$, and extension at $72{ }^{\circ} \mathrm{C}$ for $1.5 \mathrm{~min}$ for all amplicons. Annnealing temperature for D3S666 was $58{ }^{\circ} \mathrm{C}$. The program was finished by $72{ }^{\circ} \mathrm{C}$ incubation for $7 \mathrm{~min}$. The successfully amplified PCR products were then purified using the Agencourt AMPure System (Agencourt Bioscience Corporation, Beverly, MA, USA) to remove unincorporated dNTPs, primers, and salts. The purified products were then bidirectionally sequenced using the Big Dye Terminator Sequencing v1.1 CycleSeq Kit (Applied Biosystems, Foster City, CA, USA) Unincorporated dye terminators were then removed from the sequencing reaction by the Agencourt CleanSEQ system and subsequently run on an ABI Prism ${ }^{\circledR} 3130 x 1$ sequencer (Applied Biosystems). For loss of heterozygosity (LOH) analysis of neoplastic tissue DNA, STR markers D3S1768, D3S1300, D3S1317, and D3S666 located on the short arm of chromosome 3(3p) were chosen from the database (Gene Bank UniSTS).

The primers are listed in Table IV. PCR conditions were the same as mentioned above. PCR products were mixed with Gene Scan-500LIZ Size Standard (Applied Biosystems) and run on an ABI Prism 3130xl. A sample was considered LOH-positive if the ratio of non-tumor DNA to tumor DNA was $>2$ or $<0.5$.

Array comparative genomic hybridization (aCGH). DNA extraction was performed from frozen samples using NucleoSpin Kit (Macherey Nagel, Duren, Germany). Two micrograms of DNA were diluted into $80 \mathrm{~mL} \mathrm{H}_{2} \mathrm{O}$ and sonicated for 10 seconds at $10 \%$ amplitude with pulse on for 0.5 second and pulse off for 0.5 second on a Branson 450 sonicator equipped with a tapered microtip (Branson, Danbury, CT). One microgram of sonicated DNA was mixed with Random Cy labeled 7mer primers (Trilink Biotechnologies, San Diego, CA). The standard protocol included Cy3 labeling of the test sample and Cy5 labeling of the reference sample. The sample was denatured and then incubated for 2 hours at $37^{\circ} \mathrm{C}$ in a thermocycler protected from light withd NTP/Klenow Master Mix (Roche NimbleGen Inc, Madison, WI). One hundred units of Klenow Fragment 3'-5' exonucleus (NEB, Ipswich, MA) was used. The reaction was stopped by the addition of $0.5 \mathrm{~mol} / \mathrm{LEDTA}$, and the labeled sample was purified using isopropanol precipitation. Six micrograms of reference as well as the test sample were mixed, dried, and resuspended again in 5 $\mu \mathrm{L}$ of nuclease free water. As a reference, Human Genomic DNA: Male (Promega, Madison, WI) was used.

The hybridization protocol was processed using MAUI Hybridization system (BioMicro, Salt Lake City, UT) and required adhering a NimbleChip $\times 1$ mixer to the microarray slide NimbleGen 385K Human CGH WG-T v2.0, build: HG18, NCBI 36, Median Probe Spacing 7073 base pairs (bp) (Roche NimbleGen). The hybridization master mix solution was prepared using components from a NimbleGen Hybridization Kit prepared according to the NimbleGen protocol. The hybridization solution and samples were mixed, denatured, and loaded into the fill port of a mixer. The samples were then hybridized for 20 hours at 42 ${ }^{\circ} \mathrm{C}$ in mix mode B. Posthybridization washing was performed using NimbleGen buffers with increasing stringency (Roche NimbleGen). Microarrays were scanned with InnoScan 700 (Innopsys, Carbonne, France) at resolution $3 \mathrm{~mm}$. Image analysis was performed using NimbleScan 2.5 software (Roche Nimble-Gen) according to the appropriate .ndf file. The data were also processed in NimbleScan 2.5 (Roche NimbleGen) using CGH-segMNT Analysis. 
TRIVUNIC DAJKO, S.; BOGDANOVIC, J.; ANDREJIC VISNJIC, B. A.; POPOVIC, M. ; DOJLAI, M. \& HES, O. Molecular genetic analysis of primary renal epithelial tumours with granular oncocytic cytoplasm. Int. J. Morphol., 39(6):1719-1726, 2021

Table III. List of primers used for analysis of Von Hippel-Lindau (VHL) gene, L, c-kit and PDGFRA.

\begin{tabular}{|c|c|c|c|}
\hline & \multicolumn{3}{|c|}{ Primers used for analysis of VHL gene. } \\
\hline Exon & Name & \multicolumn{2}{|c|}{ Primer sequences 5'_3' } \\
\hline \multirow[t]{8}{*}{ Exon 1} & VHL el-1 & \multicolumn{2}{|c|}{ CGCGAAGACTACGGAGGT } \\
\hline & VHL el-2 & \multicolumn{2}{|c|}{ GTCTTCTTCAGGGCCGTA } \\
\hline & VHL el-3 & \multicolumn{2}{|c|}{ GAGGCAGGCGTCGAAGAG } \\
\hline & VHL el-4 & \multicolumn{2}{|c|}{ GCGATTGCAGAAGATGACCT } \\
\hline & VHL el-5 & \multicolumn{2}{|c|}{ GCCGAGGAGGAGATGGAG } \\
\hline & VHL el-6 & \multicolumn{2}{|c|}{ CCCGTACCTCGGTAGCTGT } \\
\hline & VHL el-7 & \multicolumn{2}{|c|}{ CCGTATGGCTCAACTTCGAC } \\
\hline & VHL el-8 & \multicolumn{2}{|c|}{ GCTTCAGACCGTGCTATCGT } \\
\hline \multirow[t]{2}{*}{ Exon 2} & VHL e2-1 & \multicolumn{2}{|c|}{ ACCGGTGTGGCTCTTTAACA } \\
\hline & VHL e2-2 & \multicolumn{2}{|c|}{ TCCTGTACTTACCACAACAACCTT } \\
\hline \multirow[t]{5}{*}{ Exon 3} & VHL e3-1 & \multicolumn{2}{|c|}{ GCAAAGCCTCTTGTTCGTTC } \\
\hline & VHL e3-2 & \multicolumn{2}{|c|}{ ACATTTGGGTGGTCTTCCAG } \\
\hline & VHL e3-3 & \multicolumn{2}{|c|}{ CAGGAGACTGGACATCGTCA } \\
\hline & VHL e3-4C & \multicolumn{2}{|c|}{ CCATCAAAAGCTGAGATGAAAC } \\
\hline & \multicolumn{3}{|c|}{ Primers used in mutations analysis of HOCT } \\
\hline \multicolumn{2}{|l|}{ Genes and exons } & Name & Primer sequences 5'_3' \\
\hline \multirow[t]{2}{*}{ c-kit exon $9 \mathrm{a}^{\mathrm{a}}$} & & c-kit e9aNF & GAGTAAGCCAGGGCTTTTGTT \\
\hline & & c-kit e9aNR & CGTGCCATTGTGCTTGAAT \\
\hline \multirow{2}{*}{ c-kit exon $9 b^{*}$} & & c-kit e9bNF & CCGTTTGGAAAGCTAGTGGT \\
\hline & & c-kit e9bNR & CAGAGCCTAAACATCCCCTTA \\
\hline & & c-kit el1NF & TGTTCTCTCTCCAGAGTGCTCTAA \\
\hline c-kit exon 11 & & c-kit el1NR & ACCCAAAAAGGTGACATGGA \\
\hline & & c-kit e13fN & GCCAGTTGTGCTTTTTGCTA \\
\hline c-kit exon 13 & & c-kit e13rN & TTGATAACCTGACAGACAATAAAAGG \\
\hline & & c-kit e17WF & ATGGTTTTCTTTTCTCCTCC \\
\hline c-kit exon 17 & & c-kit e17WR & TACATTATGAAAGTCACAGG \\
\hline & & PDG el2F & CTCTGGTGCACTGGGACTTT \\
\hline PDGFRA exon 12 & & PDG el2R & GGAGGTTACCCCATGGAACT \\
\hline PDGFRA exon 14 & & PDG el4fN & TGGACTGATATGTGATTTATTCTTTCA \\
\hline PDUFKA exOn 14 & & PDG e14rN & AATCCTCACTCCAGGTCAGTG \\
\hline & & PDG e $18 \mathrm{~F}$ & GCTACAGATGGCTTGATCCTG \\
\hline PDGFRA exon 18 & & PDG e18R & GACCAGTGAGGGAAGTGAGG \\
\hline & & VHL e1-1 & CGCGAAGACTACGGAGGT \\
\hline VHL exon I & & VHL e1-2 & GTCTTCTTCAGGGCCGTA \\
\hline & & VHL e1-3 & GAGGCAGGCGTCGAAGAG \\
\hline VHL exon 1 & & VHL e $1-4$ & GCGATTGCAGAAGATGACCT \\
\hline VHL exon 1 & & VHLe1-5 & GCCGAGGAGGAGATGGAG \\
\hline VHL exon 1 & & VHL e1-6 & CCCGTACCTCGGTAGCTGT \\
\hline & & VHL e1-7 & CCGTATGGCTCAACTTCGAC \\
\hline VHL exon 1 & & VHL e $1-8$ & GCTTCAGACCGTGCTATCGT \\
\hline VHL exon 2 & & VHL e2-1 & ACCGGTGTGGCTCTTTAACA \\
\hline VHL exon 2 & & VHL e2-2 & TCCTGTACTTACCACAACAACCTT \\
\hline & & VHL e3-1 & GCAAAGCCTCTTGTTCGTTC \\
\hline VHL exon 3 & & VHL e3-2 & ACATTTGGGTGGTCTTCCAG \\
\hline & & VHL e3-3 & CAGGAGACTGGACATCGTCA \\
\hline VHL exon 3 & & VHL e3-4C & CCATCAAAAGCTGAGATGAAAC \\
\hline
\end{tabular}

Legend: ${ }^{\text {a }} 5$ ' end of exon $9, * 3$ ' end of exon 9

Table IV. PCR primers used in LOH analysis of chromosome 3p.

\begin{tabular}{ll}
\hline Name & Primers (sequence 5_3_) \\
\hline D3S1768SF & GGTTGCTGCCAAAGATTAGA \\
D3S1768A & CACTGTGATTGCTGTTGGA \\
D3S1300SF & AGCTCACATTCTAGTCAGCCT \\
D3S1300A & GCCAATTCCCAGATG \\
D3S1317-1.1 & TACAAGTTCAGTGGAGAACC \\
D3S1317-1.2 & CCTCCAGGCCATACACAGTCA \\
D3S666-SK\#15 & CAAGGCATTAAAGTGGCCACGC \\
D3S666-SK\#16 & GTTTGAACCAGTTTCCTACTGAG \\
\hline
\end{tabular}




\section{RESULTS}

Applied analyses for $\mathrm{VRO}$ did not reveal presence of mutations in the $V H L$ gene, nor $\mathrm{LOH}$, and analysis of chromosomes 1, 2, 6, 7, 10, 17 showed no abnormalities. Results of $\mathrm{X}$ and $\mathrm{Y}$ chromosome testing by aCGH analysis (two cases) did not find any major chromosomal changes. A total of four clones showed losses, while one clone was discovered with the probability $0.001-0.0001$. Chromosomal changes were not present in any of the cases of psRO analyzed by aCGH, nor were numerical changes of chromosomes 7 and 17, as shown during FISH analysis, also in all three cases.

Summarized results of FISH analysis of renal HOCT are shown in Table V. There were no cases showing disomy for all tested chromosomes $(1,2,6,9,10,13,17,20,21$ and 22 ). All cases showed monosomy and polysomy for the last tested centromere. Mean number of chromosomes with numerical aberrations is 4 (ranked from 1 to 9 ).

The most common numerical aberration is monosomy of chromosome 20, which was observed in seven cases (Fig. 1A). Monosomy of chromosomes 6 and 9 was registered in four cases, two of which have monosomy of both chromosomes 6 and 9. Polysomy of chromosomes 10, 21 or 22 was present in four cases and one of the above mentioned four (case number 14) had polysomy of all of these chromosomes. LOH of the short arm of chromosome 3 (3p) was not present in successfully analyzed cases.

The results of the analysis of mutations for the VHL, c-Kit and PDGFRA genes showed that mutations could not be found in any of the analysed cases. A single nucleotide polymorphism in exon 18 of the PDGFRA gene was present in four cases. In 5 analyzed cases there were no mutations of amino acid changes, nor connected splice site mutations in the folliculin gene (FLCN) gene. Multiple exonic and individual intronic nucleotide polymorphism was detected (results not shown).

With FISH analysis of O-PRCC fluorescent signals were counted in 3372 normal and neoplastic nuclei, with the median of 99 nuclei per case. In normal epithelial cells of renal tubules, nuclei with 3 to 4 signals were occasionally noticeable, except for $12 \%$ that exceeded the number of signals, and in $20 \%$ of the cases signals were completely

Table V. FISH analysis of chromosomes 1, 2, 6, 7, 9, 10, 13, 17, 2021 and 22 in renal hybrid oncocytic/chromophobe tumours

\begin{tabular}{lccccccccccc}
\hline Case & CEP 1 & CEP 2 & CEP 6 & CEP 7 & CEP 9 & CEP 10 & LSI 13 & CEP 17 & CEP 20 & LSI 21 & LSI 22 \\
\hline 1 & D & D & D & D & D & P & D & D & M & D & D \\
2 & D & P & D & D & P & D & D & D & M & P & D \\
3 & D & D & D & D & D & P & D & D & NA & D & D \\
4 & D & M & M & D & M & M & D & D & M & M & D \\
5 & D & P & D & D & M & P & P & D & NA & D & D \\
6 & D & D & P & D & D & D & D & M & M & D & D \\
7 & P & D & P & D & M & D & D & M & M & P & P \\
8 & D & NA & NA & NA & NA & NA & NA & P & NA & NA & NA \\
9 & D & M & D & M & D & D & D & D & M & D & D \\
10 & M & D & P & D & P & D & NA & P & D & P & P \\
11 & M & M & M & P & P & M & M & D & P & D & P \\
12 & NA & D & M & D & M & M & NA & D & M & D & D \\
13 & NA & NA & M & D & NA & NA & NA & D & NA & NA & NA \\
14 & D & D & D & D & D & P & NA & D & P & P & P \\
\hline
\end{tabular}

* D-disomy, P-polysomy, M- monosomy, NA- not suitable for analysis.
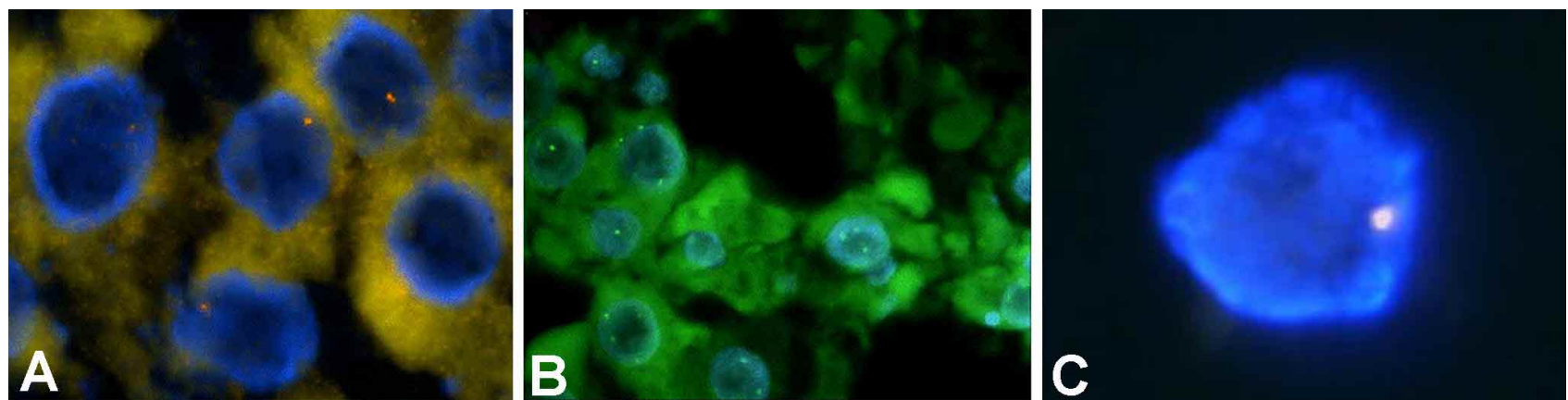

Fig. 1. Microphotographs of FISH: a) Microphotograph of FISH analysis shows monosomy of chromosome 20; b) In case 5 of O-PRCC there are 3 and more signals for both chromosomes 7 and 17; c) FISH-monosomy in PMChRCC - one intranuclear signal. 
lost. Three or more signals were often observed in tumour cells (Table VI): chromosome 7 (ranging $3-74 \%, \geq 30 \%$ in $7 / 12$ cases) and chromosome 17 (ranging $6-69 \%, \geq 30$ $\%$ in $7 / 12$ cases).

In 5 cases, three or more signals were detected for both chromosomes (Fig. 1B). Signals for chromosome Y were not present in $80-90 \%$ of nuclei. Results of PCR analysis of the mutation of exons $9,11,13$ and 17 of the ckit gene in three cases showed that there was a heterozygous $\mathrm{C}$ to $\mathrm{T}$ alteration in position 81.349. Neither mutation had effect on the amino acid sequence. Additional mutations were not present in any of the successfully analyzed cases (10 of 20). The FISH analysis were performed in all 19 patients, since case number 20 was not analyzed. In 11 cases FISH was successful, with the use of probes for chromosomes 1 ,
2, 6, 10, 13, 17 and 21. These analyses revealed a massive loss of tested chromosomes. Monosomy of chromosomes $1,2,6,10,13,21$ was found in 100, 36, 91, 82, 82 and $64 \%$ of the cases, respectively (Fig. 1C).

By using polymerase chain reactions (PCR) for granular RCC with hyaline globules the mutation of the distal part of exon 3 of the VHL gene was discovered, resulting in elongation of the VHL protein (Table VII).

Table VII. Characterization of analyzed VHL mutation in CRCC

\begin{tabular}{cccc}
\hline Exon & Nucleotid change $\dagger$ & Codon & Type of mutation \\
\hline 3 & 629delGG & 210 & Frameshift
\end{tabular}

Legend: $\dagger$ position in the coding sequence.

Table VI. Molecular genetic analysis of chromosomes 7, 17 and Y in O-PRCC.

\begin{tabular}{|c|c|c|c|c|c|c|}
\hline $\begin{array}{c}\text { Case } \\
\text { number }\end{array}$ & $\begin{array}{c}\text { CEP } 7 \\
\text { (signals) }\end{array}$ & Tnc $-\mathrm{Ts}-\%$ & CEPY & Tnc - Ts & $\frac{\text { CEP } 17}{\text { (signals) }}$ & Tnc - Ts $-\%$ \\
\hline 1 & $\geq 3$ & $8-23-69$ & loss of Y & $93-7$ & $\geq 3$ & $12-45-43$ \\
\hline 2 & 2 & $7-82-11$ & no losses & $12-88$ & $\geq 3$ & $8-30-62$ \\
\hline 3 & 3 & $6-30-64$ & loss of $Y$ & $87-13$ & 2 & $13-80-7$ \\
\hline 4 & 2 & $7-90-3$ & loss of $Y$ & $86-14$ & 3 & $10-76-24$ \\
\hline 5 & $\geq 3$ & $2-24-74$ & $\mathrm{~F}$ & // & $\geq 3$ & $10-21-69$ \\
\hline 6 & 2 & $8-89-3$ & no losses & 15.85 & 2 & $8-82-10$ \\
\hline 7 & 3 & $14-27-59$ & no losses & $16-84$ & 3 & $14-31-55$ \\
\hline 8 & $\geq 3$ & $2-26-72$ & no losses & $15-85$ & 3 & $10-31-55$ \\
\hline 9 & 3 & $8-35-57$ & $\mathrm{~F}$ & // & $\geq 3$ & $6-30-64$ \\
\hline 10 & 2 & $12-76-12$ & no losses & $16-84$ & $\geq 3$ & $7-25-68$ \\
\hline 11 & 2 & $12-75-13$ & no losses & $20-80$ & 2 & $13-79-8$ \\
\hline 12 & 3 & $17-35-48$ & no losses & $19-81$ & 2 & $13-81-6$ \\
\hline
\end{tabular}

Tnc-total number of nuclei, Ts- total number of signals, $\%$ - percent of nuclei with $\geq 3$ signals, $\mathrm{F}$ - unsuccessful analyses.

\section{DISCUSSION}

In this study we analyzed some less common subtypes of oncocytic renal tumours, such as psRO and vRO, pigmented microcystic chromophobe renal cell carcinomas and granular CRCC with hyaline globules, all for the purpose of comparison of molecular genetic characteristics with typical morphological forms of these tumours.

Although rare subtypes of RO, vRO and psRO showed absence of genetic changes in aCGH analysis, it was not a surprising result. Cytogenetically, RO are very heterogeneous tumours. There are records of RO with normal karyotype, as well as those that showed the loss of chromosomes 1 and Y (Dobin et al., 1992; Bostwick \& Cheng; McKenney et al.;). Another subspecies of RO with 11 q13 translocation was presented (Fuzesi et al., 1994; Van den Berg et al., 1995). The high incidence of abnormalities of chromosome $1 \mathrm{p}$ was documented in the series of of 27 RO, with the use of both methods, cytogenetic and FISH (Paner et al., 2007). It should be noted that aCGH analysis is only a screening method for major genetic changes and the lack of positive findings in this study does not exclude the existence of more subtle genetic aberrations.

Our series shows multiple numerical chromosomal aberrations, monosomic and polysomic. The most common numerical aberration was monosomy of chromosome 20 ( 7 cases). Monosomy of chromosome 20 is a rather unusual characteristic of renal tumours and a very unusual feature of ChRCC. Two of our cases (numbers 4 and 9) showed only multiple monosomy, without a single polysomy. In both ca- 
TRIVUNIC DAJKO, S.; BOGDANOVIC, J.; ANDREJIC VISNJIC, B. A.; POPOVIC, M. ; DOJLAI, M. \& HES, O. Molecular genetic analysis of primary renal epithelial tumours with granular oncocytic cytoplasm. Int. J. Morphol., 39(6):1719-1726, 2021

ses, monosomy was related to chromosome 2 . In these cases morphological characteristics of ChRCC, such as raisinoid nuclei, binuclear cells and clear cytoplasm, perinuclear halo, were not detected. Based on these immunophenotypic and morphological characteristics, we believe that these tumours do not represent a variant of ChRCC, the hardest differential diagnostic deliberation in HOCT (Delongchamps et al., 2009; Waldert et al., 2010).

Numerical abnormalities, trisomy of chromosomes 7 and 17, as well as the loss of the Y chromosome are specific for PRCC, and its oncocytic variant (Brunelli et al., 2005; Hes et al., 2006). Most of our analyzed cases of O-PRCC shared genetic profile of conventional PRCC: high percentage of abnormalities of chromosomes 7 and 17, and a third of cases had the loss of the Y chromosome. Polysomy of chromosomes 7 and 17 (not in a combination) was present in two of our cases, but also combined with numerical changes not typical of PRCC. Two tumours in our study did not show numerical alterations of chromosomes 7, 17 and Y. In accordance with results from this study we believe that O-PRCC is by its genetic feature, a variant of PRCC. Similar findings were documented by Tretiak et al., with the simultaneous immunohistochemical expression of racemase specific to PRCC (Tretiakova et al., 2004).

The above mentioned results were also supported by mutational screening of exons $9,11,13$ and 17 of the ckit gene, the most altered gene, in several neoplasias. We also found alteration of exon 17 at nucleotide position 81.349 in three cases. This nucleotide is third and second in the codon 798 (Ile), and the alteration had no effect on the amino acid sequence, so this is probably a rare genetic variant. Additional mutations of the c-kit gene were not found in successfully analyzed samples.

Different molecular genetic and cytogenetic analyses revealed specific chromosomal aberrations, as a common characteristic of renal cell carcinoma. Heidelberg's classification is based on these analyses. According to this classification, the loss of chromosomes 1, 2, 6, 10, 13, 17 and 21 is one of the characteristics of ChRCC (Kovacs et al., 1997). In our molecular cytogenetic analysis monosomy, as the most common alteration, in chromosomes 1, 2, 6, 10, 13, 17 and 21, was detected in all successfully analysed cases. These results correlate with analyses of ChRCC published by other authors, and support our hypothesis that PMChRCC is just an uncommon morphological variant of ChRCC, without any significant differences in their immunohistochemical and cytogenetic profiles (Speicher et al., 1994; Iqbal et al., 2000; Junker et al., 2003; Kuroda et al., 2013).

\section{CONCLUSION}

Our study determined genetic profile of some rare types of oncocytic tumours, offering insight into their thrue nature and origin. Molecular genetic analyses are an essential part of the up-to-date diagnosis of renal tumours with granular-oncocytic cytoplasm, but not the only one. The adequate diagnosis of renal epithelial tumours with granularoncocytic cytoplasm is achieved by synthesis of clinical, histomorphological, immunohistochemical, molecular genetic, and ultrastructural analysis.

TRIVUNIC DAJKO, S.; BOGDANOVIC, J.; ANDREJIC VISNJIC, B. A.; POPOVIC, M. ; DJOLAI, M. \& HES, O. Análisis genético molecular de tumores epiteliales renales primarios con citoplasma oncocítico granular. Int. J. Morphol., 39(6):1719-1726, 2021.

RESUMEN: El grupo de tumores renales primarios con citoplasma granular-oncocítico es un grupo muy heterogéneo, en su origen histológico y comportamiento biológico, resultando en problemas de diagnóstico. En el estudio se analizaron 57 tumores epiteliales renales con citoplasma oncocítico granular mediante hibridación fluorescente in situ (FISH), hibridación genómica comparativa de matriz (aCGH) y reacción en cadena de la polimerasa (PCR). Los resultados del análisis en oncocitoma renal (RO) no indicaron la presencia de mutaciones genéticas ni anomalías cromosómicas. Los tumores oncocíticos / cromófobos híbridos renales esporádicos (HOCT) tenían múltiples aberraciones numéricas de los cromosomas $1,2,6,9,10,13,17,20,21$ y 22 . No se observaron mutaciones en este tipo de tumor en el VHL, c-kit, PDGFRA y genes FLCN. El carcinoma de células renales papilar oncocítico (O-PRCC) tenía anomalías numéricas de los cromosomas 7 y 17 y la pérdida del cromosoma Y. El análisis citogenético de 20 carcinomas de células renales cromófobos microquísticos pigmentados (PMChRCC) mostró que la monosomía era la aberración más frecuente en todos los cromosomas analizados 1, 2, 5, 10, 13, 17 y 21. Un caso de carcinoma de células renales cromófobo (CCRc) hialino tenía una mutación en la parte distal del exón 3 del gen VHL. La ausencia de trastornos genéticos en la OI habitual es un resultado común, pero hemos establecido la ausencia de trastornos genéticos incluso en variantes raras. Varias alteraciones genéticas detectadas en esporádica HOCT renal demuestran que es una entidad separada, no una variante de ChRCC, mientras que PMChRCC es una variante poco común de ChRCC. O-PRCC es un subtipo de carcinoma papilar de células renales.

PALABRAS CLAVE: Tumores renales; Citoplasma oncocítico granular; Análisis genético molecular. 


\section{REFERENCES}

Adley, B. P.; Smith, N. D.; Nayar, R. \& Yang, X. J. Birt-Hogg-Dubé syndrome: clinicopathologic findings and genetic alterations. Arch. Pathol. Lab. Med., 130(12):1865-70, 2006.

Allory, Y.; Ouazana, D.; Boucher, E.; Thiounn, N. \& Vieillefond, A. Papillary renal cell carcinoma. Prognostic value of morphological subtypes in a clinicopathologic study of 43 cases. Virchows Arch., 442(4):336-42, 2003.

Bostwick, D. G. \& Cheng, L. Urologic surgical pathology. 2nd ed. Mosby, Elsevier, 2008. pp. 78-171.

Brunelli, M.; Eble, J. N.; Zhang, S.; Martignoni, G. \& Cheng, L. Gains of chromosomes 7, 17, 12, 16, and 20 and loss of Yoccur early in the evolution of papillary renal cell neoplasia: a fluorescent in situ hybridization study. Mod. Pathol., 16(10):1053-9, 2003.

Brunelli, M.; Eble, J. N.; Zhang, S.; Martignoni, G.; Delahunt, B. \& Cheng, L. Eosinophilic and classic chromophobe renal cell carcinomas have similar frequent losses of multiple chromosomes from among chromosomes 1, 2, 6, 10 and 17, and this pattern of genetic abnormality is not present in renal oncocytoma. Mod. Pathol., 18(2):161-9, 2005.

Delongchamps, N. B.; Galmiche, L.; Eiss, D.; Rouach, Y.; Vogt, B.; Timsit, M. O.; Vieillefond, A. \& Mejean, A. Hybrid tumour 'oncocytomachromophobe renal cell carcinoma' of the kidney: a report of seven sporadic cases. BJU Int., 103(10):1381-4, 2009.

Dobin, S. M.; Harris, C. P.; Reynolds, J. A.; Coffield, K. S.; Klugo, R. C.; Peterson, R. F. \& Speights, V.O. Cytogenetic abnormalities in renal oncocytic neoplasms. Genes Chromosomes Cancer., 4(1):25-31, 1992.

Fuzesi, L.; Gunawan, B.; Braun, S. \& Boeckmann, W. Renal oncocytoma with a translocation $\mathrm{t}(9 ; 11)(\mathrm{p} 23 ; \mathrm{q} 13)$. J. Urol., 152(2 Pt 1):471-2, 1994.

Gatalica, Z.; Lilleberg, S. L.; Vranic, S.; Eyzaguirre, E.; Orihuela, E. \& Velagaleti, G. Novel intronic germline FLCN gene mutation in a patient with multiple ipsilateral renal neoplasms. Hum. Pathol., 4O(12):18139, 2009.

Hes, O.; Brunelli, M.; Michal, M.; Cossu Rocca, P.; Hora, M.; Chilosi, M.; Mina, M.; Boudova, L.; Menestrina, F. \& Martignoni, G. Oncocytic papillary renal cell carcinoma: a clinicopathologic, immunohistochemical, ultrastructural, and interphase cytogenetic study of 12 cases. Ann. Diagn. Pathol., 10(3):133-9, 2006.

Iqbal, M. A.; Akhtar, M.; Ulmer, C.; Al-Dayel, F. \& Paterson, M. C. FISH analysis in chromophobe renal-cell carcinoma. Diagn. Cytopathol., 22(1):3-6, 2000 .

Junker, K.; Weirich, G.; Amin, M. B.; Moravek, P.; Hindermann, W. \& Schubert, J. Genetic subtyping of renal cell carcinoma by comparative genomic hybridization. Recent Results Cancer Res., 162:169-75, 2003.

Kluijt, I; De Jong, D.; Teertstra, H. J.; Axwijk, P. H.; Gille, J. J.; Bell, K.; van Rens, A.; van der Velden, A.W.; Middelton, L. \& Horenblas, S. Early onset of renal cancer in a family with Birt-Hogg-Dube syndrome. Clin. Genet., 75(6):537-43, 2009.

Kovacs, G.; Akhtar, M.; Beckwith, B. J.; Bugert, P.; Cooper, C. S.; Delahunt, B.; Eble, J. N.; Fleming, S.; Ljungberg, B.; Medeiros, L. J.; Moch, H.; Reuter, V. E.; Ritz, E.; Roos, G.; Schmidt, D.; Srigley, J. R.; Störkel, S.; van den Berg, E. \& Zbar, B. The Heidelberg classification of renal cell tumours. J. Pathol., 183(2):131-3, 1997.

Kuroda, N.; Tanaka, A.; Yamaguchi, T.; Kasahara, K.; Naruse, K.; Yamada, Y.; Hatanaka, K.; Shinohara, N.; Nagashima, Y.; Mikami, S.; Oya, M.; Hamashima, T.; Michal, M. \& Hes, O. Chromophobe renal cell carcinoma, oncocytic variant: A proposal of a new variant giving a critical diagnostic pitfall in diagnosing renal oncocytic tumours. Med. Mol. Morphol., 46(1):49-55, 2013.

McKenney, J. K.; Tickoo, S. K. \& Paner, G. P. Diagnostic pathology: Genitourinary. 1st ed. Amirsys, Canada; 2010. pp. 2-230.

Merino, M. J.; Eccles, D. M.; Linehan, W. M.; Algaba, F.; Zbar, B.; Kovacs, G.; Kleihues, P.; Geurts van Kessel, A.; Kiuru, M.; Launonen, V.; Herva, R.; Aaltonen, L. A.; Neumann, H. P. H. \& Pavlovich, C. P. Familial renal cell carcinoma. In: Eble, J. N.; Sauter, G.; Epstein, J. I. \& Sesterhenn, I. A, Ed. World Health Organization Classification of tumours. Pathology and genetics tumours of the urinary system and male genital organs. IARC Press, Lyon, 2004. pp.15-22.

Paner, G. P.; Lindgren, V.; Jacobson, K.; Harrison, K.; Cao, Y.; Campbell, S. C.; Flanigan, R. C. \& Picken, M. M. High incidence of chromosome 1 abnormalities in a series of 27 renal oncocytomas: cytogenetic and fluorescence in situ hybridization studies. Arch. Pathol. Lab. Med., 131(1):81-5, 2007.

Speicher, M. R.; Schoell, B.; du Manoir, S.; Schrock, E.; Ried, T.; Cremer, T.; Störkel, S.; Kovacs, A. \& Kovacs, G. Specific loss of chromosomes $1,2,6,10,13,17$, and 21 in chromophobe renal cell carcinomas revealed by comparative genomic hybridization. Am. J. Pathol., 145(2):356-64, 1994.

Tretiakova, M. S.; Sahoo, S.; Takahashi, M.; Turkyilmaz, M.; Vogelzang, N. J.; Lin, F.; Krausz, T.; The, B. T. \& Yang, X. J. Expression of alphamethylacyl-CoA racemase in papillary renal cell carcinoma. Am. J. Surg. Pathol., 28(1):69-76, 2004.

Van den Berg, E.; Dijkhuizen, T.; Störkel, S.; de la Riviere, G. B.; Dam, A.; Mensink, H. J.; Oosterhuis, J. W. \& De Jong, B. Chromosomal changes in renal oncocytomas Evidence that $\mathrm{t}(5 ; 11)(\mathrm{q} 35 ; \mathrm{q} 13)$ may characterize a second subgroup of oncocytomas. Cancer Genet. Cytogenet., 79(2):164-8, 1995.

Waldert, M.; Klatte, T.; Haitel, A.; Ozsoy, M.; Schmidbauer, J.; Marberger, M. \& Remzi, M. Hybrid renal cell carcinomas containing histopathologic features of chromophobe renal cell carcinomas and oncocytomas have excellent oncologic outcomes. Eur. Urol., 57(4):6615,2010 .

Corresponding author:

Bojana Andrejic Visnjic

Hajduk Veljkova 321000

Novi Sad

SERBIA

E-mail: bojana.andrejic-visnjic@mf.uns.ac.rs

Received: 08-07-2021

Accepted: 13-09-2021 